\title{
Evaluation of the Quality of Perinatal Assistance in the Municipality of São Luís-Ma
}

\author{
Cleide Maria Macedo Pimenta* \\ Postgraduate Program in Management of Health Programs and Services at Ceuma University \\ Rua Josué Montello, nº 1, Bairro Renascença II, São Luís, Maranhão, Brazil, 65075-120 \\ Janaina Maiana Abreu Barbosa \\ Professor of the Medicine Course at Ceuma University \\ Rua Josué Montello, nº 1, Bairro Renascença II, São Luís, Maranhão, Brazil, 65075-120 \\ Adriana Sousa Rêgo \\ Postgraduate Program in Management of Health Programs and Services at Ceuma University \\ Rua Josué Montello, nº 1, Bairro Renascença II, São Luís, Maranhão, Brazil, 65075-120 \\ Marcia Rodrigues Veras Batista \\ Professor of the Medicine Course at Ceuma University \\ Rua Josué Montello, nº 1, Bairro Renascença II, São Luís, Maranhão, Brazil, 65075-120 \\ Daniel Carvalho de Matos \\ Professor of the Psychology Course at Ceuma University \\ Rua Josué Montello, nº 1, Bairro Renascença II, São Luís, Maranhão, Brazil, 65075-120 \\ Wellyson da Cunha Araújo Firmo \\ Postgraduate Program in Management of Health Programs and Services at Ceuma University \\ Rua Josué Montello, nº 1, Bairro Renascença II, São Luís, Maranhão, Brazil, 65075-120 \\ Cristina Nitz da Cruz \\ Professor of the Law Course at Ceuma University \\ Rua Josué Montello, nº 1, Bairro Renascença II, São Luís, Maranhão, Brazil, 65075-120 \\ Flor de Maria Araújo Mendonça Silva \\ Postgraduate Program in Management of Health Programs and Services at Ceuma University \\ Rua Josué Montello, nº 1, Bairro Renascença II, São Luís, Maranhão, Brazil, 65075-120
}

\section{This research was not funded.}

\section{Abstract}

Women and newborns must receive quality care during the perinatal period. Prenatal care is important for health care, including health promotion, screening, diagnosis, and disease prevention. This study aimed to evaluate the quality of perinatal care in the city of São Luís-MA. A cross-sectional analytical study was carried out with 201 pregnant women in three Health Districts of São Luís-MA, from January to December of 2019. For data collection, the perinatal form, which is attached to the medical records of pregnant and postpartum women, was used. Regarding the data, it was observed that in the age variable, there was a predominance of the age group between 21-34 years (71.64\%), with a higher prevalence for 6 appointments performed: $96(75.00 \%)(\mathrm{p}=0.31)$. Regarding marital status, $82.59 \%$ were married, with a higher prevalence for 6 appointments performed: $106(82.81 \%)$ $(\mathrm{p}=0.91)$. As for education, high school predominated $(68.18 \%)$ and with a higher prevalence for 6 appointments performed: $92(71.88 \%)(\mathrm{p}=0.28) .83 .08 \%$ did not plan the pregnancy, with a higher prevalence for 6 appointments performed: $103(80.47 \%)(\mathrm{p}=0.19)$. As for the beginning of prenatal care, $85.07 \%$ in a timely manner, with a higher prevalence for 6 appointments performed: $122(95.31 \%)(\mathrm{p}=0.00) .90 .55 \%$ were immunized, with a higher prevalence for 6 appointments performed: $124(96.88 \%)(\mathrm{p}=0.00)$. Only 5.47\% had a postpartum appointment, with statistical significance $(\mathrm{p} \leq 0.10)$. The study allowed us to observe that some indicators are satisfactory, such as immunization and timely start of prenatal care. As for unsatisfactory indicators, there is the puerperal appointment, the values of which are below the recommended.

Keywords: Quality of Assistance. Perinatal Assistance. Primary Care.

DOI: $10.7176 /$ RHSS/11-22-04

Publication date: November $30^{\text {th }} 2021$ 


\subsection{INTRODUCTION}

Prenatal care is defined as a set of actions and attention aimed at women's health during the gestational period, aiming to ensure a better health condition, avoiding death and physical impairment of the mother and fetus. In view of the Brazilian reality and the decisive role of prenatal care in the gestational outcome, the need arose to define a national model that would standardize care actions related to prenatal care, combining efforts to sensitize managers and health professionals with the objective to implement a broad and critical vision, improve obstetric care in the country. Thus, in June 2000, the Prenatal Care and Birth Humanization Program (PHPN) was implemented by the Ministry of Health, through GM ordinance $n^{\circ} 569$ (ROCHA; SILVA, 2012).

Prenatal care comprises one of the most complete sets of health care offered to a specific population group. Its potential impact on maternal-infant morbidity and mortality is widely known, both by the reduction in the occurrence of premature childbirth, pregnancy-specific hypertensive disease, and gestational diabetes, as well as by the decrease in the severity of cases. It is estimated that a quarter of infant and maternal deaths result from the lack of adequate prenatal care. For this reason, offering this type of service should be an absolute priority in all realms of municipal, state, or federal government (SAAVEDRA; CESAR, 2015).

The World Health Organization (WHO) envisions a world in which all women and newborns receive quality care throughout pregnancy, childbirth, and the postnatal period. Within the reproductive health care cycle, prenatal care (PNC) provides a platform for important health care functions, including health promotion, screening, diagnosis, and disease prevention. It is proven that, with the timely and appropriate implementation of evidencebased practices, (PNC) can save lives.

For Tomasi et al. (2017) quality perinatal care is able to reduce maternal-infant morbidity and mortality, as the identification of gestational risk by the professional allows for adequate guidance and referrals at each stage of pregnancy. In 2014, about $40 \%$ of the 10,446 preventable infant and neonatal deaths that occurred in Brazil were related to inadequate care during pregnancy (TOMASI et al., 2017).

Perinatal outcomes are the result of a complex network of factors that include biological, socioeconomic, and care determinants. Perinatal care can contribute to more favorable outcomes by allowing the detection and timely treatment of conditions, in addition to controlling risk factors that bring complications to the health of women and babies (DOMINGUES et al., 2012).

For pregnant women at usual risk, the PHPN established basic rules for qualified and humanized care, recommending the first prenatal appointment $(\mathrm{PN})$ before the fourth month of pregnancy, a minimum of six prenatal appointments (one in the first trimester of pregnancy, two in the second, and three in the third) and the puerperal appointment up to 42 days after delivery (CORRÊA et al., 2014) in addition to laboratory tests: Blood count, ABO-Rh, VDRL, EAS, urine culture with antibiogram, fasting blood glucose, HIV, HBsAg, IGG toxoplasmosis, IGM, hemoglobin electrophoresis, and obstetric ultrasound, administration of tetanus, influenza, and hepatitis B vaccines, educational activities, classification of gestational risk to be carried out in the first appointment and in subsequent appointments. It is also necessary to ensure that pregnant women classified as at risk have the service and access to the referral unit for outpatient and/or hospital care for high-risk pregnancy (BRASIL, 2002).

The Ministry of Health, aiming to expand quality care in the perinatal period, brought new proposals and, in 2011, launched the Rede Cegonha strategy, based on the principles of SUS (Unified Health System), in order to ensure universality, equity, and comprehensiveness of health care, in order to provide women with health, quality of life, and well-being during pregnancy, childbirth, postpartum, and child development up to the first two years of life. Also aiming to reduce maternal and infant mortality and guarantee the sexual and reproductive rights of women, men, youth, and adolescents (MARQUES, 2016).

National studies with local coverage have shown the existence of failures in prenatal care, such as difficulties in accessing, late start, inadequate number of appointments, and incomplete performance of the recommended procedures, affecting its quality and effectiveness. The lack of linkage between the services that provide prenatal care and childbirth is another problem identified, resulting in the pilgrimage of pregnant women in labor in search of a place for hospitalization, bringing additional risks to the health of the parturient and the newborn (VIEELAS et al, 2014).

According to data provided by the Ministry of Health, the State of Maranhão, in 2016, had the second highest maternal mortality rate in the country. The average reached 122 cases for every 100,000 born. The high rates are related to the poor quality of health care in the perinatal period (GUARDA, 2017). The Municipality of São Luís, after joining the Rede Cegonha, presented a $43 \%$ reduction in the number of maternal deaths registered in the last four years. The positive numbers are the result of a set of initiatives aimed at improving and humanizing care for pregnant women through the offer of new services (AGÊNCIA, 2017).

According to Anversa et. al. (2012), assessment of the quality of care at health units is an important guiding tool for managers and health professionals. Evaluating perinatal care can contribute to improving the care of pregnant women, reducing maternal and perinatal morbidity and mortality rates. After all, it is known that adherence and continuity of prenatal care are related to the quality of care provided by the service and health 
professionals, and that such adherence is essential to reduce the high rates of maternal and perinatal mortality observed in Brazil.

In this sense, the objective of this study was to evaluate the quality of perinatal care in the city of São LuísMA.

\subsection{METHODS}

Cross-sectional analytical study conducted with 201 pregnant women in the Health Districts of Bequimão, Coroadinho, and Cohab in the Municipality of São Luís-MA, from January to December of 2019. In the municipality of São Luís, the health network is divided into Health Districts according to the location of health units, to facilitate management, consisting of seven districts, however three were selected, due to the higher concentration of pregnant women.

For data collection, the perinatal form was used, which makes up the information relevant to the follow-up and was attached to the medical records of pregnant and postpartum women. As inclusion criteria, pregnant women from the $36^{\text {th }}$ week of pregnancy until the puerperium were selected.

Data collection began with the analysis of eligible medical records and those who did not have a completed perinatal form, or an incomplete form were excluded from the research. The necessary criteria were used to classify the quality of care, according to the Childbirth Humanization Program and the Rede Cegonha of the Ministry of Health.

The collected data were typed and analyzed using STATA 14.0 software (Stata Corp., College Station, Texas, USA). Descriptive statistics included calculation of absolute and relative frequencies. Nominal categorical variables and association between the explanatory and response variables were performed using the test for independent samples.

In the univariate analysis, the associated factors were assessed between the explanatory variable (perinatal care) and the response variable (quality of perinatal care). The associated factors were assessed in relation to the response variable, with their respective Prevalence Ratio (PR) and 95\% confidence intervals (95\% CI), statistical significance $(\mathrm{p} \leq 0.05)$ and the number of those exposed in the sample. The multivariate analysis was performed using the logistic regression model for variables with $\mathrm{p}<0.20$ and were selected for inclusion in the multivariate model, with those with $\mathrm{p}<0.10$ remaining in the final multivariate model.

The study is part of a larger survey conducted by the CEUMA University in partnership with the Secretariat of State and Health/MA (SES) entitled "Evaluation of healthcare coverage in women's health and infant mortality in Maranhão."

\subsection{RESULTS}

The age variable, age group between 21-34 years, has a higher frequency: 144 (71.64\%) and with higher prevalence for 6 appointments performed: $96(75.0 \%)$, with no statistical significance $(\mathrm{p}=0.31)$. The marital status variable, with higher frequency for married: $166(82.59 \%)$ and with higher prevalence for 6 appointments performed: 106 $(82.81 \%)$ with no statistical significance $(\mathrm{p}=0.91)$. Education is more frequent for high school: $137(68.16 \%)$ and with higher prevalence for 6 appointments performed: $92(71.88 \%)$ with no statistical significance $(p=0.28)($ Table $1)$.

In Table 2, the variable immunization has a higher frequency: $182(90.55 \%)$, with a higher prevalence for 6 appointments performed: $124(96.88 \%)$ with statistical significance $(\mathrm{p}=0.00)$. The timely start of prenatal variable has a higher frequency: 171 (85.07\%), with a higher prevalence for 6 appointments performed: $122(95.31 \%)$, with no statistical significance $(\mathrm{p}=0.00)$. The puerperal appointment variable has a higher frequency: $190(94.53 \%)$, with no statistical significance ( $\mathrm{p}=0.10)$ and a higher prevalence for 6 appointments: $117(91.41 \%)$. The unplanned pregnancy variable has a higher frequency: 167 (83.08\%), with a higher prevalence for 6 appointments performed: $103(80.47 \%)$, with no statistical significance $(\mathrm{p}=0.19)$.

Table 3 presents the unadjusted analysis of socioeconomic and demographic data. The variables planned pregnancy and puerperal appointment were statistically significant $(\mathrm{p} \leq 0.01)$. The variable immunization $(\mathrm{p}=0.02)$ and timely start of prenatal care $(p=0.03)$ also showed statistical significance.

The adjusted analysis referring to table 3 also revealed the following results for the planned pregnancy variable $(\mathrm{p}=0.26 ; \mathrm{RP}=0.88 ; \mathrm{IC}=0.71-1.09)$; for the variable immunization $(\mathrm{p}=0.03 ; \mathrm{RP}=2.57 ; \mathrm{IC}=1.08-6.14)$; for the timely start of prenatal care $(\mathrm{p}<0.001 ; \mathrm{RP}=2.96 ; \mathrm{IC}=1.44-6.08)$; and, finally, for the puerperal appointment variable $(\mathrm{p}<0.001 ; \mathrm{RP}=0.10 ; \mathrm{IC}=1.22-1.52)$.

\subsection{DISCUSSION}

Perinatal care involves not only health-related issues, but all the factors that can interfere with the pregnancy stage, so when clinically evaluating a pregnant woman, it is extremely important to know the sociodemographic, economic, and clinical characteristics. Among the variables found in this study, it was observed that the data related to age group corroborate other studies carried out in some basic health units (UBS), located in urban and rural 
areas of the 5,565 municipalities in Brazil, which showed a higher percentage in the range aged 20 to 34 years $(68.2 \%)$, in addition to other national studies carried out in Sarandi (PR) and Aracaju (SE) (TOMASI et al., 2017).

The findings of this research showed that $82.59 \%(\mathrm{p}=0.91)$ lived in a stable relationship or were married, which is in line with another research carried out by Vilela and Pereira (2018) with $85.64 \%$ married and $13.89 \%$ single, also showing close to national data from the Information Technology Department of the Unified Health System (DATASUS), in which $70.9 \%$ of women have the same marital status profile.

This information is important, as it shows that most women can count on the presence of a partner in the pregnancy cycle (Vilela; Pereira, 2018). Different data related to marital status were found in the study by Saavedra and Cesar (2015) with 2,395 women in the city of Rio Grande, in which only $27.5 \%$ said they had a stable marital status (SAAVEDRA; CESAR, 2015).

In the present study, it was observed that women with high school were the majority: $68.18 \%(\mathrm{p}=0.28)$, and there was no case of illiteracy. In a similar study, Corrêa et al. (2014) found that $64.01 \%$ had completed high school, and there was only one case of illiteracy. Other studies such as by Derlan et al. (2015) found only $30 \%$ of women who had completed high school. Education is a variable that should be considered in women's health care, as women with less education are the biggest victims of maternal mortality, indicating that they are possibly not being adequately assisted and neither are the risks of death being corrected (MASCARENHAS et al., 2017).

In Brazil, most pregnancies are unplanned and many of them result in abortion, constituting an important factor for maternal morbidity and mortality (EVANGELISTA; BARBIERI; SILVA, 2015). This study confirms the national reality, as we found that pregnancies were not planned in $83.08 \%$, another study such as that by Bonatti et al. (2018) showed similar values, with 75\%, while a work completed by Bayer (2014) lists that 55\% of Brazilian pregnant women do not plan their pregnancy, as shown in the study "Nascer Brasil," these data are higher than those found by the National Demographic and Health Survey (46\%). These results serve as a warning, as it is estimated that every year, eighty million women in the world experience an unwanted pregnancy and $60 \%$ do not progress to the end (EVANGELISTA; BARBIERI; SILVA, 2015).

The timely start of prenatal care allows access to diagnostic and therapeutic methods for various pathologies with serious repercussions for the health of women and babies. Suitability in the city of São Luís, according to the data found in this study, showed a prevalence of $85.07 \%$ and with statistical significance $(\mathrm{p}=0.00)$, representing a higher value when compared to another study conducted throughout the national territory, involving 23,940 women, in which $75.8 \%$ had started in the first trimester (POLGLIANE et al., 2014).

A similar study conducted in Campina Grande showed lower data when compared to other realities, in which $55.5 \%$ of women had their first appointment in the first trimester of pregnancy, with a prevalence of $79.2 \%$ in the Neonatal Call for the Northeast. Similar results were found in the "Nascer Brasil" survey, pointing out that 73.7\% of pregnant women in this region started prenatal care during the same period of pregnancy. These results can have negative repercussions for pregnant women, as the beginning of timely prenatal care enables early identification of risky pregnancies, as well as the number of prenatal appointments and exams necessary to preserve maternal and child health (PEDRAZA, 2016).

In the postpartum appointment, assessment of the mother's and newborn's health status and the interaction between them should be considered; support for breastfeeding; identification and management of risk situations; family planning guidance; and the return to pre-pregnancy conditions (ROCHA; SILVA, 2012). However, Tsunechiro et al. (2018) affirm the existence of few studies that analyze the puerperal return and that the pregnancy should only be considered as concluded after the puerperal appointment.

Rocha and Silva (2012) conducted a study with the objective of evaluating the Childbirth Humanization Program and pointed out the scarce performance of puerperium appointments in most Brazilian municipalities. A possible cause for this fact is an incomprehension of the relevance of this appointment on the part of the mothers, including a lack of encouragement from the health professional during the prenatal period for pregnant women to return to the Health Unit for the postpartum review because what is observed is that, often, puerperal women return to the Health Unit not for their postpartum appointment, but for the newborn's immunization. The National Survey of women's and children's Demography and Health (PNDS-2006) revealed that in only 39.0\% of births, the woman had a postpartum appointment, showing that this important stage of care has really been neglected in the country. Other studies have shown higher percentages 48.0\% (BRASIL, 2008) and 62.2\% (OLIVEIRA et al., 2013), however, lower than other work published in 2018 in São Paulo, in which 2,204 pregnant women were evaluated and $77.9 \%$ returned to the appointment after delivery (TSUNECHIRO et al., 2018). On the other hand, the data from this research revealed how low the puerperal appointment was in São Luís - MA, as only 5.47\% returned to the appointment after delivery, being far below all the works analyzed.

The Ministry of Health (BRASIL, 2013) recommends that adequate care must ensure good vaccination coverage, as it is essential to prevent vaccine-preventable diseases for both the mother and the fetus (SILVA, 2018). In the present study, in the effectiveness of immunization, a prevalence of $90.55 \%$ of pregnant women immunized during prenatal care was observed $(\mathrm{p}=0.03)$. Lower results were found by Polgliane et al. (2014), whose vaccination coverage was $70.6 \%$, but close to the results found by Martinelli et al. (2014) in a study conducted in 
the city of São Mateus-ES, where tetanus immunization was administered to $58.7 \%$ of the evaluated pregnant women. Low vaccine coverage implies greater risks for the emergence of neonatal tetanus (SANTOS FILHO, 2015).

\subsection{CONCLUSION}

Considering the data obtained, the quality of perinatal care in the city of São Luís - MA showed satisfactory results in relation to what is proposed by the MS, such as the early start of prenatal care and immunization. However, it needs improvement regarding the number of appointments and, mainly, regarding the puerperal appointment. Low coverage of ESF in the municipality may be contributing to these negative indicators. In addition, deficiencies in care were evidenced, such as failures in the registration of procedures, exams, and immunization, which compromise the quality of the PN offered. Therefore, it is important to emphasize the importance and need to encompass the basic standards recommended by PHPN and Rede Cegonha for the realization of a qualified and humanized care to obtain positive perinatal outcomes.

We observed difficulty in capturing data through the perinatal form, as some medical records do not have the form and present insufficient information. One measure to improve these results would be the implementation of the PEC in all Basic Health Units so that there is a better use of data related to care. It is believed that this alternative is an instrument that will contribute to improve the PN indicators.

The results of this assessment have great potential to help health managers, by presenting the deficient points of perinatal care offered, and can support decision-making in order to formulate coping strategies for the problems that affect the quality of care provided to women during this period.

In view of the aspects observed, it is clear that studies evaluating the quality of care have shown to be excellent tools for the analysis of conditions related to the quality of prenatal care. Thus, they contribute as an instrument for future studies related to the implementation of new actions, policies and strategies that promote the improvement of support services for pregnant women.

\section{References}

AGENCIA - SÃO LUÍS, Agência São Luís. Rede Cegonha São Luís. 2017. Access on: https://oimparcial.com.br. Anversa, E. T. R., Bastos, G. A. N., Nunes, L. N., Pizzol, T. S. D. (2012). Qualidade do processo da assistência pré-natal: unidades básicas de saúde e unidades de Estratégia Saúde da Família em município no Sul do Brasil. Cad. Saúde Pública, 28(4), 789-800.

BAYER. (2014). Descuido e uso incorreto de métodos contraceptivos são a principal causa da gravidez não planejada. Available in https:/www.bayer.com.br/midia/noticias/visualiza-noticia.php? codNoticia=26-desetembro-dia-mundial-da-prevencao-da-gravidez-nao-planejada.

Bonatti, A. F., Santos, G. W. S., Ribeiro, T. A. N., Santos, D. A. S., Olinda, R. A., Oliveira, J. C. S. (2018). Fatores Associados ao Tipo de Gestação não Planejada na Estratégia de Saúde da Família. Rev Fund Care Online, 10(3), 871-6.

BRASIL. Ministério da Saúde. Secretaria Executiva. Programa: Humanização do parto Humanização no Pré-natal e nascimento. Brasília DF. 2002.

BRASIL. Ministério da Saúde. Secretaria de Atenção à Saúde. Departamento de Atenção Básica. Atenção ao Prénatal de baixo Risco. Cadernos de Atenção Básica, $n^{o}$ 32. $1^{a}$ edição revista. Brasília: Editora do Ministério da Saúde, 2013b.

Corrêa, M. D., Tsunechiro, M. A., Lima, M. O. P., Bonadio, I. C. (2014). Avaliação da assistência pré-natal em unidade com estratégia saúde da família. Rev Esc Enferm, 48(Esp), 24-32.

Derlan, C. B. D., Bassani, D. C. H., Chaves, J., Kanitz, L., Ghignatti, B., Koep, J., ...\& Possuel, L. G. (2015). Avaliação de pré-natal por indicador de qualidade. J Health Biol Sci, 3(2), 67-72.

Domingues, R. M. S. M., Hartz, Z. M. A., Dias, M. A. B. Leal, M. C. (2012). Avaliação da adequação da assistência pré-natal na rede SUS do Município do Rio de Janeiro, Brasil. Cad Saude Publica, 28(3), 425-37.

Evangelista, C. B., Barbieri, M., Silva, P. L. N. (2015). Gravidez não planejada e fatores associados à participação em programa de planejamento familiar. Rev Pesqui (Univ. Fed. Estado Rio J., Online), 7(2), 2464-74.

GUARDA, O. I. D. (2017). Mortalidade Materna no Estado do Maranhão. Dissertação. Universidade Federal do Maranhão.

MARQUES, C. P. C. (2016). Redes de atenção a saúde: a rede cegonha. Universidade Federal do Maranhão. UNA-SUS/UFMA.

Mascarenhas, P. M., Silva, G. R., Reis, T. T., Casotti, C. A., Nery, A. A. (2017). Análise da Mortalidade Materna. Rev enferm UFPE on line, 11(Supl. 11), 4653-62.

Oliveira, R. L. A. Fonseca, C. R. B. Carvalhaes, M. A. B. L., Parada, C. M. G. L. (2013). Avaliação da atenção pré-natal na perspectiva dos diferentes modelos na atenção primária. Rev. Latino-Am. Enfermagem. 21(2), 18.

ORGANIZAÇÃO MUNDIAL DA SAÚDE (OMS). (2016). Recomendações da OMS sobre cuidados pré-natais 
para uma experiência positiva na gravidez.

Pedraza, D. F. (2016). Assistência ao pré-natal, parto e pós-parto no município de Campina grande, Paraíba. Cad Saúde Colet. 24(4), 460-67.

Polgliane, R. B. S., Leal, M. C., Amorim, M. H. C., Zandona, E. Santos Neto, E. T. (2014). Adequação do processo de assistência pré-natal segundo critérios do Programa de Humanização do Pré-natal e Nascimento e da Organização Mundial de Saúde. Ciênc saúde coletiva, 19(7), 1999-2010.

Rocha, S. R., Silva, M. G. C. (2012). Assistência pré-natal na rede básica de Fortaleza - CE: Uma avaliação da estrutura, do processo e do resultado. Rev Brasileira Promoção Saúde, 25(3), 344-55.

Saavedra, J. S., Cesar, J. A. (2015). Uso de diferentes critérios para avaliação da inadequação do pré-natal: um estudo de base populacional no extremo Sul do Brasil. Cad Saúde Pública, 31(5), 1003-14.

Santos Filho, D. A. (2015). Qualidade da Assistência Pré-Natal na Estratégia Saúde da Família em Duque de Caxias-RJ. Monografia. Universidade do Estado do Rio de Janeiro

Universidade Aberta do SUS.

SILVA, M. B. da. (2018). Análise da Cobertura Vacinal da Gestante de Risco Habitual em São Luís - MA. Monografia. Universidade Federal do Maranhão.

Tsunechiro, M. A., Pimentel, M. O. L., Bonadio, I. C., Corrêa, M. D., Silva, A. V. A. Donato, S. C. T. (2018). Avaliação da assistência pré-natal conforme o Programa de Humanização do Pré-natal e Nascimento. Rev Bras Saude Mater Infant, 18(4), 781-90.

Tomasi, E., Fernandes, P. A. A., Fischer, T., Siqueira, F. C. V., Silveira, D. S. Thumé, E.

Duro, S. M. S., ... \& Facchin, L. A. (2017). Qualidade da atenção pré-natal na rede básica de saúde do Brasil: indicadores e desigualdades sociais. Cad Saúde Pública, 33(3):e00195815.

Viellas, E. F., Domingues, R. M. S. M., Dias, M. A. B., Gama, S. G. N., Theme Filha, M. M., da Costa, J. V., ... \& Maria do Carmo Leal. (2014). Assistência pré-natal no Brasil. Cad. Saúde Pública, 30 (Suppl 1).

VILELA, M. L. F.; PEREIRA, Q. L. C. (2018). Consulta puerperal: orientação sobre sua importância. J. Health NPEPS, 3(1), 228-40.

Table 1. Distribution of sociodemographic variables of perinatal assistance in the city of São Luís-MA, 2021.

\begin{tabular}{|c|c|c|c|c|}
\hline \multirow[b]{2}{*}{ Variables } & \multirow[b]{2}{*}{$\mathbf{N}(\%)$} & \multicolumn{2}{|c|}{ Number of Appointments } & \multirow{2}{*}{ p-value } \\
\hline & & $<6$ Appointments & >6 Appointments & \\
\hline Age (years) & & & & 0.31 \\
\hline $14-20$ & $41(20.40)$ & $17(23.29)$ & $24(18.75)$ & \\
\hline $21-34$ & $144(71.64)$ & $48(65.75)$ & $96(75.00)$ & \\
\hline $35-41$ & $16(7.96)$ & $8(10.96)$ & $8(6.25)$ & \\
\hline Marital status & & & & 0.91 \\
\hline Single & $35(17.41)$ & $13(17.81)$ & $22(17.19)$ & \\
\hline Married & $166(82.59)$ & $60(82.19)$ & $106(82.81)$ & \\
\hline Education & & & & 0.28 \\
\hline Elementary/Middle school & $32(15.92)$ & $13(17.81)$ & $19(14.84)$ & \\
\hline High school & $137(68.16)$ & $45(61.64)$ & $92(71.88)$ & \\
\hline University education & $32(15.92)$ & $15(20.55)$ & $17(13.28)$ & \\
\hline
\end{tabular}

Source: Survey data from January to December/2019. $\mathrm{p} \leq 0.05$. 
Table 2. Distribution of variables related to the current pregnancy of perinatal assistance in the city of São LuísMA, 2021.

\begin{tabular}{|c|c|c|c|c|}
\hline \multirow[b]{2}{*}{ Variables } & \multirow{2}{*}{$\mathbf{N}(\%)$} & \multicolumn{2}{|c|}{ Number of Appointments } & \multirow{2}{*}{ p-value } \\
\hline & & $<6$ Appointments & $>6$ Appointments & \\
\hline Immunized & & & & 0.00 \\
\hline No & $19(9.45)$ & $15(20.55)$ & $4(3.12)$ & \\
\hline Yes & $182(90.55)$ & $58(79.45)$ & $124(96.88)$ & \\
\hline Timely start of prenatal care & & & & 0.00 \\
\hline No & $30(14.93)$ & $24(32.88)$ & $6(4.69)$ & \\
\hline Yes & $171(85.07)$ & $49(67.12)$ & $122(95.31)$ & \\
\hline Puerperal appointment & & & & 0.10 \\
\hline No & $190(94.53)$ & $73(100.00)$ & $117(91.41)$ & \\
\hline Yes & $11(5.47)$ & $0(0.00)$ & $11(8.59)$ & \\
\hline Planned pregnancy & & & & 0.19 \\
\hline No & $167(83.08)$ & $64(87.67)$ & $103(80.47)$ & \\
\hline Yes & $34(16.92)$ & $9(12.33)$ & $25(19.53)$ & \\
\hline
\end{tabular}

Table 3. Unadjusted and adjusted analysis of the age variable in relation to perinatal clinical variables in the city of São Luís-MA, 2021

\begin{tabular}{|c|c|c|c|c|c|c|}
\hline \multirow[t]{2}{*}{ Variables } & \multicolumn{3}{|c|}{ Unadjusted analysis } & \multicolumn{3}{|c|}{ Adjusted analysis } \\
\hline & PR & CI & p-value & PR & CI & p-value \\
\hline Planned pregnancy & & & 0.00 & & & \\
\hline No & 1 & 1 & - & 1 & 1 & - \\
\hline Yes & 0.83 & $0.66-1.06$ & 0.14 & 0.88 & $0.71-1.09$ & 0.26 \\
\hline Immunized & & & 0.02 & & & \\
\hline No & 1 & 1 & - & 1 & 1 & - \\
\hline Yes & 3.23 & $1.34-7.79$ & $<0.001$ & 2.57 & $1.08-6.14$ & 0.03 \\
\hline $\begin{array}{c}\text { Timely start of prenatal } \\
\text { care }\end{array}$ & & & 0.03 & & & \\
\hline No & 1 & 1 & - & 1 & 1 & - \\
\hline Yes & 3.56 & $1.72-7.35$ & $<0.001$ & 2.96 & $1.44-6.08$ & $<0.001$ \\
\hline Puerperal appointment & & & $<0.001$ & & & \\
\hline No & 1 & 1 & - & 1 & 1 & - \\
\hline Yes & 1.62 & $1.45-1.81$ & $<0.001$ & 0.10 & $1.22-1.52$ & $<0.001$ \\
\hline
\end{tabular}

